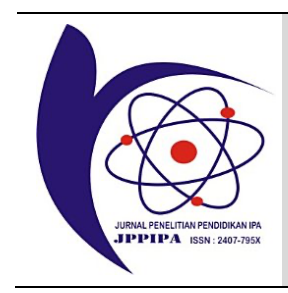

\title{
The Influence of the Use of Student Worksheet Problem-Based to Increase Problem Solving Skills and Learning Outcomes
}

\author{
Oka Melawati1 ${ }^{1}$ Evendi², A. Halim²*, Yusrizal2 ${ }^{2}$, Elisa $^{2}$ \\ ${ }^{1}$ Science Education Study Program, Postgraduate, Universitas Syiah Kuala, Banda Aceh, Indonesia \\ ${ }^{2}$ Physics Education Study Program, Faculty of Teacher Training and Education, Universitas Syiah Kuala, Banda Aceh, Indonesia
}

DOI: $\underline{10.29303 / \text { jppipa.v8i1.1205 }}$

\section{Article Info}

Received: December 4, 2021

Revised: January 15, 2022

Accepted: January 23, 2022

Published: January 31, 2022

\begin{abstract}
Problem-solving skills are the needs of students in the 21st century so they are deemed necessary to have. One of the 2013 curriculum imposed by the government focuses students on problem-solving skills. The purpose of this study was to identify the influence of using problem-based Student worksheets on improving problem-solving skills and student learning outcomes on business and energy materials. This study uses a quantitative approach with a quasi-experimental research design. student worksheet implementation design uses One Group Pretest-Posttest Design. The instruments used in this study were problem-based students' worksheets, problem-solving skills tests, and learning outcomes tests. The problem-solving skills of students were analyzed using the N-Gain test to see the effect before and after the problem-based student worksheet was implemented. The results of the student worksheet feasibility test obtained a percentage of $98.30 \%$ indicating that the student worksheet problem-based to improve problem-solving skills and learning outcomes is very feasible to use. The results of the implementation of problem-based student worksheets can improve students' problem-solving skills which are marked by an increase in the pretest-posttest value based on the results of the experimental class N-gain test of 0.93 in the high category, the control class $\mathrm{N}$-gain value of 0.60 in the medium category. The learning outcomes test showed an increase in the $\mathrm{N}$-gain value for the experimental class by 0.71 in the high category, the N-gain value for the control class by 0.50 in the medium category.
\end{abstract}

Keywords: Student worksheet problem-based; Problem-solving skills; Learning outcomes.

Citation: Melawati, O., Evendi, E., Halim, A., Yusrizal, Y., \& Elisa, E. (2022). The Influence of the Use of Student Worksheet Problem-Based to Increase Problem Solving Skills and Learning Outcomes. Jurnal Penelitian Pendidikan IPA, 8(1), 346-355. https://doi.org/10.29303/ippipa.v8i1.1205

\section{Introduction}

Curriculum 2013 imposed by the government one of which focuses students on problem-solving skills. It is listed in the Permendikbud No. 81A (2013) which states that learners need to be encouraged to work to solve problems, find everything for themselves, and work hard to realize their ideas. The importance of problem-solving skills Is also expressed by Huitt, (1992) who states that the transition to the information age has focused attention on the process of problem-solving and decision making. One of the forms of thinking skills high level that must be provided is problem-solving skills. This skill is very important for students to remember they now live in a world that is increasingly complex (Sutarno, et al, 2017). In accordance with the opinion, Rusman (2011) stated that problem-based learning makes students acquire the knowledge and concepts that are the essence of the subject matter. Learners build the concept or principle of their own accord that integrates the skills and knowledge that has been understood previously. Learners who possess problem-solving skills (problem-solving skills) are both typically have the skills to think better. Problem-solving skills learners need to be measured, especially in the field of physics to know how the readiness of learners to face the challenges of the 21st century (Hidayat, et al., 2017). 
Physics is one of the sciences which plays an important role in the advancement of technology. Physics is seen as a process and at the same time the product so learning should consider the strategy or method of learning that is effective and efficient. The nature of physics so that students are required to perform an activity of scientific knowledge and scientific attitude to develop the ability to think critically, analyze problems better, think systematically, and tend to seek the truth before deciding learning (Handriani, et al., 2015). Learning physics is basically can not be equated with other learning, this is because not all materials physics can be described or presented directly. Learning physics is part of science the scientific need of the concept of thinking and understanding that will be integrated into the development of the skills of analysis and systems thinking. Learning physics has the objective to develop the knowledge, understanding, and analytical skills of the students towards the environment and its surroundings. Learn physics students are expected to not only master the concepts but also to apply concepts that they have understood in physics problem-solving. However, learning in the classroom tends to emphasize the mastery concept and rule out the problem-solving skills of physics students (Hoellwarth, et al., 2005).

Learning physics in Indonesia at this time is focusing on how to help students in improving cognitive knowledge but does not help the learners to learn how to apply scientific concepts that have been studied in real life outside of school (Koedinger, et al., 2012). The problems that often occur in the field of learners do not have the opportunity to develop the ability to think because the learning process applied to still centered on the teacher (teacher-centered), thus causing the students to become passive. Based on the results of preliminary observations about the presence of the device of learning and student learning outcomes that have been conducted in SMAN 1 Woyla there are some obstacles in the learning process, as the process of teaching and learning is still teacher center learning tools that have not been adequate during the learning process. This fact is visible from the learners listening to more material from the teacher and taking notes of what the teacher gives, it makes students less active and less excited in doing the tasks given.

The low learning outcomes of physics students at SMAN 1 Woyla look at the results of the national exam of physics district/city level in the last three years. This suggests the occurrence of a decline from the years 2016, 2017, and 2018 with a value that is 72,26, 25,71, and 26,25. Furthermore, the value of the national exam of the academic year 2016, 2017, and 2018 on the material of effort and energy also occurs a decrease in the 52,17, 47,35, and 40,91 (Puspendik, 2015). The results of the observation in SMAN 1 Woyla, in the implementation of learning activities, is still a lot of learners it is difficult to understand the lessons of physics. The process of learning does not provide access for students to develop independently in finding their knowledge. So that will have an impact on the ability to think and skills are never trained that cause learner difficulty to solve a problem.

One of the solutions that can be done to improve the skills of the students in resolving problems and improve your problem-solving skills as well as learning outcomes, is necessary to create an environment of learning fun that is by using the model of problem-based learning. Model Problem-based learning is a learning model that is suitable for use in resolving the problem. Problem-solving emphasizes the provision of direct experience to the students in problem-solving physics.

In addition, the learning model also required the device of learning that can improve the skills of learners. One of the learning tools that can improve the skills of learners is that student worksheet a student worksheet is a guide for learners to perform activities of investigation or problem-solving. Student worksheets can be a guide to developing a cognitive aspect and a guide for developing all aspects of learning (Trianto, 2009). Student worksheet problem-based is a student worksheet that can help the learners find the concept. On learning that uses student worksheet problem-based, the concept can be found independently by learners (Zulfah, 2018).

Based on the above description then researched the Influence of student worksheet Problem-Based to Increase Problem Solving Skills and Learning Outcomes on the Material of Effort and Energy in SMAN 1 Woyla. A student worksheet is expected to become a choice in implementing the learning of physics to increase problem-solving skills and learning outcomes of students.

\section{Method}

The type of research used in this research is quasiexperiment design with Nonequivalent Control Group Design (Sugiyono, 2012). This research was conducted by giving the treatment to the experimental group and providing a control group for comparison.

Table 1. Research design one group pretest-posttest Design

\begin{tabular}{llll}
\hline Class & Pretest & Treatment & Posttest \\
\hline Experiments & $\mathrm{O}_{1}$ & $\mathrm{X}_{1}$ & $\mathrm{O}_{2}$ \\
Control & $\mathrm{O}_{3}$ & $\mathrm{X}_{2}$ & $\mathrm{O}_{4}$ \\
\hline & & \multicolumn{3}{c}{ (Sugiyono, 2008) }
\end{tabular}

Description:

$\mathrm{X}_{1}=$ Treatment using student worksheet problem-based $\mathrm{X}_{2}=$ Treatment does not use student worksheet problem-based 
$\mathrm{O}_{1}=$ The value of Pre-test class experiments

$\mathrm{O}_{2}=$ The value of the posttest experimental class

$\mathrm{O}_{\mathrm{a}}=$ The value of the Pre-test control class

$\mathrm{O}_{4}=$ The value of posttest control class

The population in this research is all students of class XI MIA SMAN 1 Woyla academic year 2021/2022 derived from 2 classes, namely the experimental class and the control class with a student population of 62 people. While the class of experiments in this research is class XI MIA1 and that becomes the control class in this research is class XI MIA2 selected by simple random sampling or random sampling without regard to strata that exist in the population with the members of the population considered to be homogeneous (Sugiyono, 2008).

The instruments used in this research are the validation sheet student worksheet, test your problemsolving skills and test of learning outcomes. Data collection techniques in this research are pretest and posttest. The Pre-test is used to determine the extent of your problem-solving skills and student learning outcomes before using student worksheet problembased, while the post-test was used to determine the effect of the use of student worksheet problem-based to increase problem-solving ability and student learning outcomes after using student worksheet problem-based. The test of pretest and posttest to measure problemsolving skills which consist of the 5 points about the description and test questions to measure the learning outcomes which consists of 20 items of multiple-choice questions that have been in the validation. In addition to the questions test problem-solving skills and learning about the test results student worksheet problem-based used also the first in the validation by experts in their field before use when teaching and learning process to determine the level of feasibility.

Data analysis techniques in this study using the test $\mathrm{N}$-gain using Microsoft excel to determine the increase in problem-solving ability and learning outcomes obtained by students. N-gain is obtained in the normalization by the difference between the maximum score with the scores of the initial test. The changes that occur before and after the learning is calculated with the formula of the N-Gain by Hake (1999).

$$
\mathrm{N} \text {-gain }=\frac{s \text { post }-s \text { pre }}{s \text { mahs }-s \text { pre }} \times 100
$$

The N-Gain obtained is used to see an increase in students ' understanding of concepts before and after learning with the learning model PBL-based experiments.
Table 2. N-Gain

\begin{tabular}{ll}
\hline N-Gain & Criteria \\
\hline $0,71-1,00$ & Hight \\
$0,31-0,70$ & Currently \\
$0<0,30$ & Low \\
\hline
\end{tabular}

(Hake: 1999)

Then the normality of the data and the hypothesis test obtained were tested by using the statistical test of one sample Kolmogorov Smirnov test and independent samples test using SPSS software version 20.

\section{Result and Discussion}

This study aims to see the influence of the use of student worksheet problem-based to increase problemsolving skills and learning outcomes of students on the material of effort and energy. Data collection in this research is the validation of student worksheets, test your problem-solving skills, and test of learning outcomes of students on the material of effort and energy. In addition, the learning device as well as test your problem-solving skills and test of learning outcomes test the feasibility and validation with two people validators that are experts in the field of evaluation and learning tools.

This study aims to see the influence of the use of student worksheet problem-based to increase problemsolving skills and learning outcomes of students on the material of effort and energy. Data collection in this research is the validation of student worksheets, test your problem-solving skills, and test of learning outcomes of students on the material of effort and energy. In addition, the learning device, as well as test your problem-solving skills and test of learning outcomes, test the feasibility and validation with two people validators that are experts in the field of evaluation and learning tools.

Table 3. Student worksheet Validity Analysis Results

\begin{tabular}{lll}
\hline Aspects Assessed & Value (\%) & Criteria \\
\hline $\begin{array}{l}\text { Format student } \\
\text { worksheet }\end{array}$ & $100 \%$ & Very Worthy \\
$\begin{array}{l}\text { Systematic student } \\
\text { worksheet }\end{array}$ & $95 \%$ & Very Worthy \\
$\begin{array}{l}\text { Language and } \\
\text { Writing }\end{array}$ & $100 \%$ & Very Worthy \\
Average & $98.30 \%$ & Very Worthy \\
\hline
\end{tabular}

Table 3, in the top rating average percentage of all aspects, obtained is $98.30 \%$ showed student worksheet made classified in the category of very worthy. In addition, given pretest for the experimental class and the control class to determine problem-solving skills and learning outcomes of students before using student worksheet problem-based. 
Improving student problem-solving skills is not only seen from the value of the pretest and posttest but also judged by the increase in each of the steps to problem-solving. As for the troubleshooting steps that are used in this research are the steps of problem-solving according to Heller, et al (1992), namely: (1) Focusing problems, here the students visualize the problem using the sketch, write down what is known and asked; (2) Draw the situation of physics, here the learners simplify the situation in the form of an image of the situation of physics or diagram complete with the use of a variable in mathematics that is specific or concept of physics is required; (3) Plan the solution, here the learners find the relationship between the equations or lower the equation so obtained a new equation; (4) Carry out the plan, here learners complete the solution by entering the numbers (quantitative) complete with the units used so that the acquired what became the target of the problem; (5) Evaluation, here. learners re-check all the steps that have been done, see the accuracy of the answers and the suitability of the answers to the questions. In accordance with the research obtained, it proves that the use of Discovery Learning student worksheets is better than conventional student worksheets in improving students' Critical Thinking Skills (Rizki, 2021).

Improve problem-solving skills learners judging by the increase in each of the steps to problem-solving. Improved every step of problem-solving is also supported by the student worksheet used. Learners are familiarized to understand the problem, to be solved in accordance with the stages of the solution contained in the student worksheet problem-based. The average score of N-Gain based on indicators problem-solving skills can be seen in figure 1

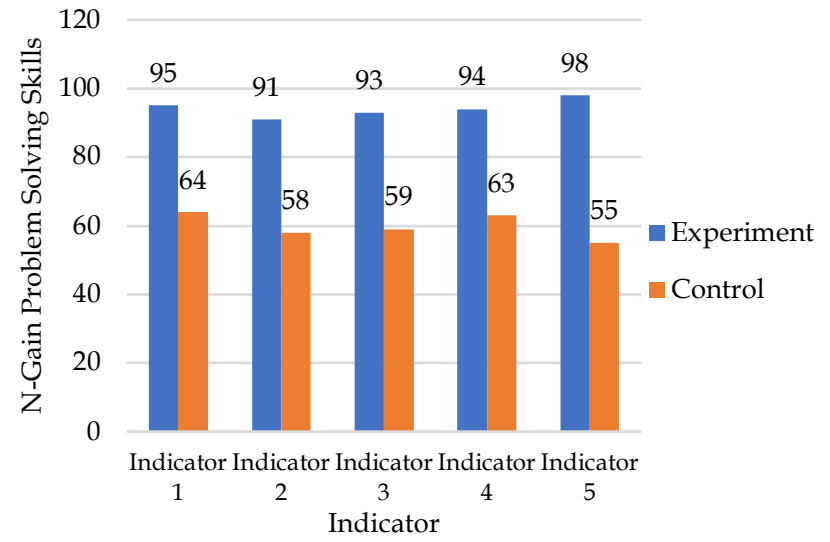

Figure 1. The average value Pretest - Posttest Experimental Class and Control

Based on Figure 1, the percentage of the average Ngain of each indicator problem-solving skills in the experimental class obtained the high category, while in the control class obtained the medium category. It is proved that student worksheet problem-based influential in improving the problem-solving ability of learners. This is in accordance with the results of research conducted by Mahardika, et al. (2017) that student worksheet problem-based influence the problem-solving skills of learners. The difference in the average $\mathrm{N}$-gain of the second class can be caused by the spirit of learning when applying student worksheet problem-based. Student worksheet problem based contains the troubleshooting steps that make students more focused when experimenting, so that students are more enthusiastic in carrying out the learning process. Problem-based learning is very effective applied in the learning process, in addition, enhancing problemsolving skills can also improve students ' understanding of concepts in a matter of effort and energy. The average value of $\mathrm{N}$-gain problem-solving skills per indicator the experimental class and control class can be seen in Table 4.

Table 4. The average N-Gain Problem Solving Skills Experimental Class and Control

\begin{tabular}{lll}
\hline \multirow{2}{*}{$\begin{array}{l}\text { Indicator problem-solving } \\
\text { skills }\end{array}$} & $\begin{array}{l}\text { N-Gain problem-solving } \\
\text { skills }\end{array}$ \\
\cline { 2 - 3 } & Experiments & Control \\
\hline Focusing problems & 0.909 & 0.641 \\
Describe the situation of physics & 0.910 & 0.587 \\
Planning the solution & 0.930 & 0.598 \\
Implement the plan & 0.949 & 0.632 \\
The evaluation of the answer & 0.984 & 0.550 \\
\hline
\end{tabular}

Based on Table 4, the percentage of the average Ngain of each indicator problem-solving skills in the experimental class obtained the high category, while in the control class obtained the medium category. As for the indicators of problem-solving in the experimental class with student worksheets problem-based with an average high is the evaluation of the answers, while in the control class with the average high is the focus of the problem. This is because in the experimental class learners can resolve the issue up to the stage of evaluating, namely student worksheet problem-based used when the process of learning effect on problemsolving skills at the stage of evaluation. In the control class, the mean of the highest indicators focusing problems is because the learners are only able to solve the problem until at the stage of a focusing problem. This is in accordance with the results of the research conducted by Halim, et al. (2017) which states that overall students were able to apply problem-solving strategies with the right, though the second stage (describe the problem) has not performed well. This is because the respondents did not know the contents of the solution is required at this stage.

Based on the test $\mathrm{N}$-gain can be seen in Table 4 . overall, there is an increased problem-solving ability with the high category. This can be seen in Table 4 . that the $\mathrm{N}$-gain the highest occurred in the step of evaluating the answers (check and evaluate). The increase of 
troubleshooting steps that are rated based on the ability of students in solving problems after using student worksheet problem-based. Before using student worksheet problem-based learners solve problems at the stage of implementation of the plan that learners are required to implement the plan in accordance with the solutions that have been planned. In carrying out the plan to solve the problem students are required to be able to calculate the data of the problem so that the results are obtained in accordance with the problem. After being taught using student worksheets problem-based learners can evaluate the problems with the right. Overall, each indicator's problem-solving ability increased after applying student worksheet problem-based. This suggests that student worksheet problem-based is more suitable to increase the problem-solving ability of learners.

Student worksheet problem based can assist learners in identifying and solving the problems on the material of effort and energy. Indicator problem-solving skills in Table 4 show that the N-Gain for each indicator problemsolving in the experimental class is higher than the control class. Based on the results obtained it is student worksheet problem-based can be used as a learning device to improve the problem-solving skills of learners. It is proved that student worksheet problem-based influential in improving the problem-solving skills of learners. This is in accordance with the results of the research of Falenti 2019) that student worksheet problem-based can improve the problem-solving skills of problem-solving in learning biology. In addition to problem-solving skills student worksheets based on the issues that affect the ability of critical thinking and student learning outcomes in the material of environmental pollution, as well as there is a significant relationship between the ability to think critically with the learning outcomes of students (Khairunnisa, 2016). According to research results, there are differences in critical thinking abilities and environmental care attitudes of students who use the PBL e-module model based on the wetland environment and use textbooks commonly used in schools (Aufa, et al., 2021).

Based on the value of $\mathrm{N}$-gain then the data were analyzed with a normality test and hypothesis test. The results of the normality test for each step problemsolving normal distribution, which means that the distribution of the data for the experimental class and the control class in all the steps of problem-solving normal distribution. The results of the hypothesis test for each of the troubleshooting steps can be seen in Table 5 .
Table 5. Hypothesis Test the Hypothesis Indicator Problem Solving Skills

\begin{tabular}{|c|c|c|c|}
\hline \multirow{2}{*}{$\begin{array}{l}\text { Indicator problem- } \\
\text { solving skills }\end{array}$} & \multicolumn{2}{|l|}{$t_{\text {test }}$} & \multirow[t]{2}{*}{ Description } \\
\hline & $t_{\text {count }}$ & $t_{\text {table }}$ & \\
\hline Focusing Problems & 15.660 & 2.001 & Significant \\
\hline $\begin{array}{l}\text { Describe the Situation } \\
\text { of Physics }\end{array}$ & 14.736 & 2.001 & Significant \\
\hline Planning the Solution & 15.566 & 2.001 & Significant \\
\hline Implement the Plan & 16.227 & 2.001 & Significant \\
\hline $\begin{array}{l}\text { The Evaluation of } \\
\text { Answer }\end{array}$ & 26.442 & 2.001 & Significant \\
\hline
\end{tabular}

Based on the hypothesis test was obtained a significant result means that the use of student worksheet problems-based on the experimental class can affect the increasing problem-solving skills of learners compared with the control class that does not use student worksheets problem-based. In line with the results of the research of Juliawan, et al., (2017), a model of problembased learning affects the problem-solving ability of learners from conventional learning models. Student worksheet problem-based in addition to can improve your problem-solving skills can also improve the learning outcomes of students. The learning outcomes of students on the material of effort and energy in this research were obtained from the value of the pretest, posttest, and $\mathrm{N}$-gain, to determine the increase in student learning outcomes between the experimental class with the control class in SMAN 1 Woyla. The increase in student learning outcomes between the experimental class can be seen in Figure 2.

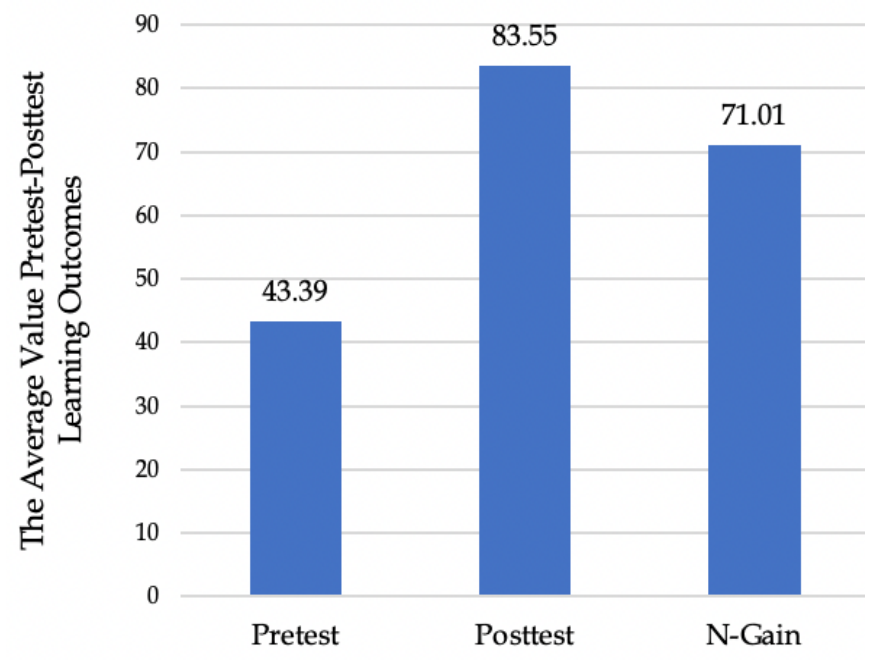

Figure 2. The Average of Learning Outcomes of Experimental Class

Based on Figure 2, an increase in the value of pretest and posttest of students of the experimental class after using the help of student worksheet problem-based. Ngain test pretest-posttest learning outcomes of the experimental class at the high category. The 
improvement of learning outcomes of students of class experiments can be seen in Figure 3.

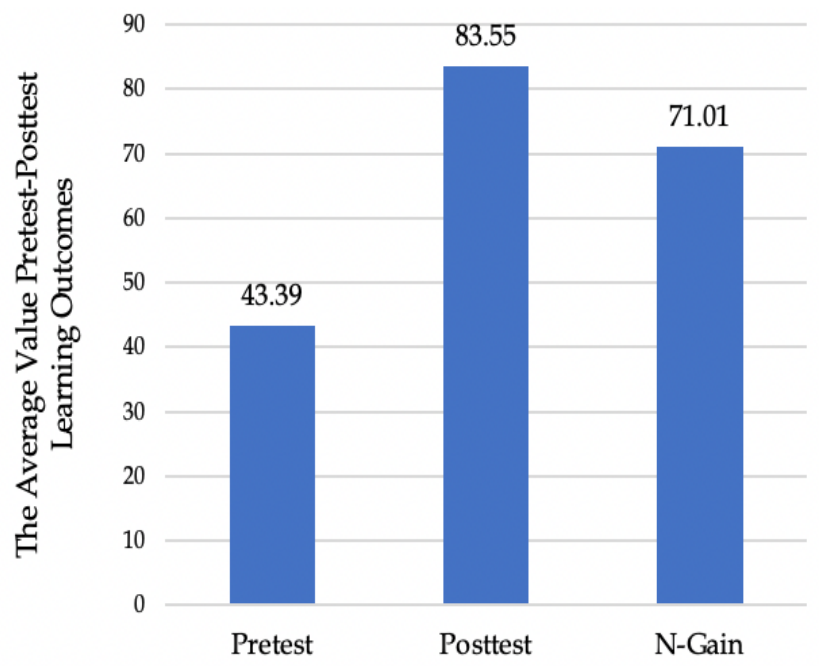

Figure 3. The Average of Learning Outcomes of Control Class

Based on Figure 3, an increase in the value of pretest and posttest of students of the experimental class after using the help of student worksheet problem-based. $\mathrm{N}$ gain test pretest-posttest learning outcomes in the control class are in the category of being.

The learning outcomes of students on the material of effort and energy in this research, in addition to analyzing the overall also analyzed based on the cognitive level of each question to measure the test results of the learning. To determine the improvement of learning outcomes based on the level of cognitive matter of $\mathrm{C} 2$ and $\mathrm{C} 3$ class experiments can be seen in Figure 4.

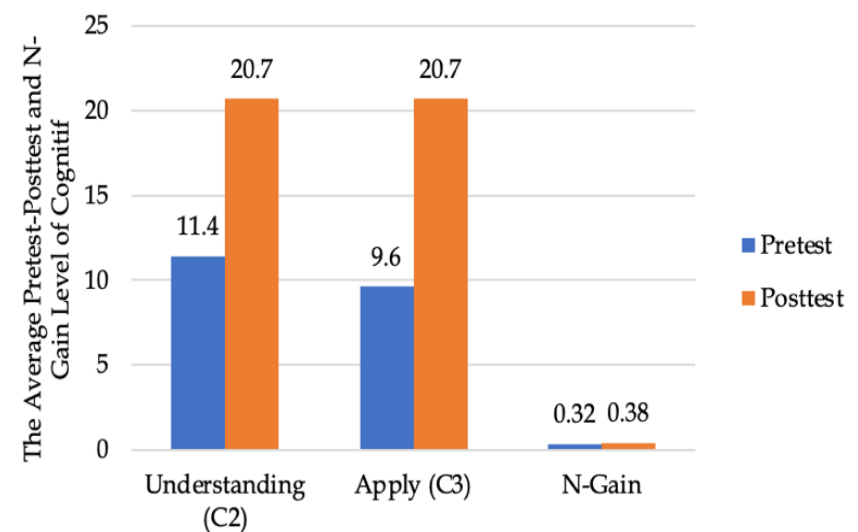

Figure 4. Learning outcomes Cognitive Level C2 and C3 Class Eskperimen
The improvement of learning outcomes based on the level of cognitive matter of C2 and C3 class control can be seen in Figure 5.

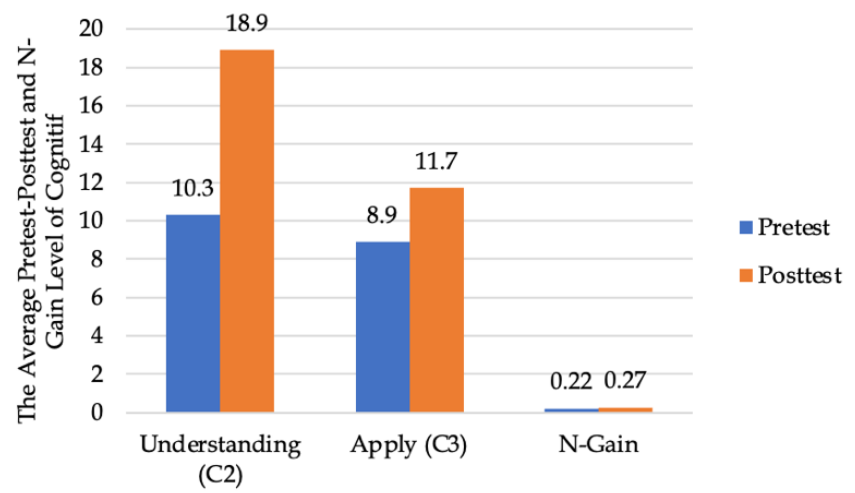

Figure 5. Cognitive Level Learning gains C2 and C3 control Classes

The learning outcomes of students in addition to views based on the results of pretest and posttest were also analyzed based on the level of cognitive learning about the test results. Learning about the test results that are used include cognitive understanding (C2) and application (C3). Cognitive understanding (C2) in the experimental class obtained $\mathrm{N}$-gain of 0.32 , cognitive apply (C3) obtained N-Gain of 0.38 . The learning outcomes of students on the test cognitive understanding $(\mathrm{C} 2)$ on the control class obtained N-Gain of 0.22 and on the cognitive domain applying (C3) obtained N-Gain of 0.27 . The difference in the value of $\mathrm{N}$-gain between the two classes is adrift far enough, which means student worksheet problem-based influence the improvement of learning outcomes of students in the experimental class than in class control taught using student worksheet no problem-based. According to research results of Evendi and Verawati, (2021), within the framework of classroom action research which was carried out in two cycles, the results showed that there was an increase in student learning outcomes from cycle I to cycle II. The use of the PBL model can improve student learning outcomes.

Based on the value of $\mathrm{N}$-gain then the data were analyzed with a normality test and hypothesis test. Based on the normality test and hypothesis test (t-test) with the help of SPSS software version 20 to determine the effect of the use of student worksheet problem-based learning outcomes of students. The results of the analysis, normality test, and hypothesis test can briefly be seen in Table 6 .

Table 6. Data normality test and test hypothesis learning outcomes

\begin{tabular}{llllll}
\hline \multirow{2}{*}{ Class } & \multirow{2}{*}{ The Average N-Gain } & \multirow{2}{*}{ Normality $\left.{ }^{*}\right)$} & $t_{\text {test** }}$ & & \multirow{2}{*}{ Description } \\
\cline { 3 - 5 } & & & $t_{\text {test* }^{* *}}$ & $t_{\text {test** }}$ & \\
\hline Exsperiment & 0.71 & 0.782 & 5.08 & 2.001 & There are significant Diferences \\
Control & 0.50 & 0.596 & 5.08 & 2.001 & There are significant Diferences \\
\hline
\end{tabular}

Description:*) Test Kolmogorov-Smirnov Test, If the Sig. $>0.050$ (Normal) $\left.{ }^{* *}\right) t_{\text {test }}$ If $t_{\text {count }}>t_{\text {table }}$ ( there is a significant difference) 
The value of the t-table is obtained by counting the degrees of freedom, the value of the degrees of freedom equal to the number of respondents reduced the number of study variables with a significant level of 0.05 . In this study the number of respondents as many as 62 people and the number of research variables, namely 3 variables, so that the obtained degrees of freedom is 59 . Degrees of freedom and significance level have then obtained the value of $t_{\text {table }}$ of 2.001 .

The test results of $\mathrm{N}$-gain of the second class are obtained that $t_{\text {count }}(5.08) \geq t_{\text {table }}(2.001)$ at a significant level of 0.05. It can be explained that in the experimental class and control there is a difference, which means the use of student worksheet problem-based can improve the learning outcomes of students. This is in accordance with the results of the research by Fajria, et al., (2017), stated that there are significant differences between the experimental class and control with the applied learning model problem-based learning (PBL). In addition, research conducted by Selvianti, et al., (2013) showed that the troubleshooting method can improve student learning outcomes. This is in accordance with the results of research conducted by Raehanah, et al., (2014) that the application of a problem-based learning model can improve student learning outcomes on the material buffer solution. According to research results of Amalya, et al. (2021), there are differences in student learning outcomes after applying the Problem Base Learning model combined with E-STEM-based student worksheets on environmental pollution materials at MAN Banda Aceh. In addition, students' critical thinking skills improved through the PBL learning model assisted by PhET (Rahmadita, et al., 2021).

Improve learning outcomes obtained by students from the experimental class are also caused by learning activities to the stages of problem-based learning as stated in the student worksheet problem-solving. This stage requires students to find and analyze a problem independently and find solutions for any problems acquired during the process so that student learning outcomes can be improved. Learners in this stage are trained to search for and analyze each problem up to the point of its roots and complete independently through the troubleshooting steps found on student worksheet problem-based learning. Problem-based learning will train the skills of learners in solving the problem and finding answers to themselves (Rahayuni, 2016). Through problem-based learning, students can build problems and establish the basic skills because, in the process of learning, learners are guided to defend the argument by giving the reason (Noprianda, et al., 2016). Problem-based learning methods practicum can improve student learning outcomes is high compared with a class that does not implement problem-based learning. Problem-based learning methods practicum has a positive effect on the students to acquire the meaningful knowledge (Zahrah, et al., 2017).

From the results of the meta-analysis that has been carried out regarding the effectiveness of the use of student worksheets in science learning, it can be concluded that based on the calculation of effect size, there is an effect of using Student Worksheets in science learning on student learning outcomes (Chutami and Suhartini, 2021). Learning using student worksheet problem-based can affect the improvement of student learning outcomes, this is in accordance with the results of the research of Zurraturrahmi, et al. (2016) that student worksheet problem-based can improve student learning outcomes on the subject of a mirror with $\mathrm{N}$-gain 50,92 with the criteria of being. Learning with student worksheets is also very useful for students because in addition to supporting learners to learn actively and independently also can improve the learning outcomes to the fullest. Therefore, the use of student worksheet problem-based can improve student learning outcomes (Gunada, et al., 2015).

Based on the results of the research by Nuraina, et al. (2021), it can be concluded that the design of students' worksheet-based Missouri Mathematics Project in teaching mathematics and physics integrated with students' local wisdom is considered appropriate to be developed. The expert of media and material of the worksheet valued respectively $89.66 \%$ and $91.52 \%$ to be in the category of "valid". As such, the students' worksheets can be applied in the classroom as the teaching materials and for the independent study.

This is in accordance with the results of the study of Fatmawati, et al. (2021), worksheets based on creative problem solving as an alternative in the learning process, in course implementation by adjusting the materials in biology subjects. The limited test results proved that students had not been able to answer questions in some indicators of creative problem-solving.

Problem-based learning models in addition to improving learning outcomes can also improve critical thinking skills, this is in accordance with research by Menap, et al. (2021), the PBL model proved to be effective in improving students' critical thinking skills. Student worksheets can not only improve learning outcomes and problem-solving skills, but they can also improve understanding of concepts. According to research results of Doyan, et al. (2021) it can be concluded that the development of multi-representation-based worksheets is effective for increasing mastery of concepts.

\section{Conclusion}

Based on the results of research conducted in general student worksheet problem-based worthy is used to increase problem-solving skills and learning outcomes of students on the material of effort and 
energy. Based on the results of data analysis it can be concluded that: (1) there is an influence of the use of student worksheet problems based on improved problem-solving skills, it can be seen from the value of $\mathrm{N}$-gain between the pretest-posttest experimental class of 0.93 is in the category of high, to the control class by 0.60 are in the medium category; (2) there is an influence of the use of student worksheet problem based on increasing the learning outcomes of students, it can be seen from the value of $\mathrm{N}$-gain between pretest-posttest experimental class was 0.71 at the high category, for the control class of 0.50 was in the medium category.

\section{Acknowledgments}

Based on the conclusion above, the writer suggests to the teacher to be able to apply student worksheet problembased in the process of learning physics or other learning. To further research the authors suggest continuing this research with how to make questions test problem-solving skills that can direct the students to solve the problem up to the stage of evaluating the answers.

\section{References}

Amalya, C. P., Artika, W., Safrida, S., Nurmaliah, C., Muhibbuddin, M., \& Syukri, M. (2021). Implementation of the Problem Base Learning Model combined with E-STEM Based Student Worksheets on Learning Outcomes and Self Efficacy on Environmental Pollution Materials. Jurnal Penelitian Pendidikan IPA, 7(Speciallssue), 37-38. https://doi.org/10.29303/ippipa.v7iSpeciallssue.9 $\underline{62}$

Andriani, N. (2015). Pengaruh Metode Pembelajaran Kooperatif Dan Gaya Kognitif Terhadap Hasil Belajar IPA Siswa Kelas V Sekolah Dasar Negeri 147 Palembang. Jurnal Pendidikan Dasar, 6(2), 276 - 286. https://doi.org/10.21009/JPD.062.08

Aufa, M. N., Rusmansyah, R., Hasbie, M., Jaidie, A., \& Yunita, A. (2021). The Effect of Using e-module Model Problem Based Learning (PBL) Based on Wetland Environment on Critical Thinking Skills and Environmental Care Attitudes. Jurnal Penelitian Pendidikan IPA, 7(3), 401-407. https://doi.org/10.29303/jppipa.v7i3.732

Chutami, F., \& Suhartini, S. (2021). The Effectiveness of Using Student Worksheets in Science Learning on Student Learning Outcomes. Jurnal Penelitian Pendidikan IPA, 7(4), 587-592. https://doi.org/10.29303/jppipa.v7i4.768

Doyan, A., Rahman, M. M., \& Sutrio, S. (2021). Development of Student Worksheets Based on a Multi-Representation Approach to Improve
Students' Mastery of Sound Wave Concepts. Jurnal Penelitian Pendidikan IPA, 7(SpecialIssue), 175-179. https://doi.org/10.29303/jppipa.v7iSpeciallssue.1 $\underline{201}$

Evendi, E. ., \& Verawati, N. N. S. P. (2021). Evaluation of Student Learning Outcomes in Problem-Based Learning: Study of Its Implementation and Reflection of Successful Factors. Jurnal Penelitian Pendidikan IPA, 7(Speciallssue), 69-76. https://doi.org/10.29303/jppipa.v7iSpecialIssue.1 099

Fajria, F., Rahmatan, H., \& Halim, A. (2018). Dampak Model Pembelajaran Problem Solving Terhadap Motivasi Dan Hasil Belajar Peserta Didik Di SMP. Jurnal Pendidikan Sains Indonesia, 5, 87-94. https:// doi.org/10.24815/jpsi.v5i2.9822

Falenti, R.M. (2019). Pengembangan Lembar Kerja Siswa (Lks) Berbasis Problem Based Learning (Pbl) Terhadap Kemampuan Pemecahan Masalah Pada Mata Pelajaran Biologi Di Sma/Ma Bandar Lampung. Skripsi. Fakultas Tarbiyah and Teacher training. Universitas Islam Negeri Raden Intan.

Fatmawati, B., Wazni, M. K., \& Husnawati, N. (2021). The Study of Worksheets Based on Creative Problem Solving for Biology Subjects. Jurnal Penelitian Pendidikan IPA, 7(4), 701-706. https://doi.org/10.29303/jppipa.v7i4.831

Gunada, I., Sahidu, H., \& Sutrio, S. (2017). Pengembangan Perangkat Pembelajaran Fisika Berbasis Masalah untuk Meningkatkan Hasil Belajar dan Sikap Ilmiah Mahasiswa. Jurnal Pendidikan Fisika dan Teknologi, 1(1), 38-46. http://dx.doi.org/10.29303/jpft.v1i1.233

Hake, R. (1999). Interactive-Engagement Versus Traditional Methods: A Six-Thousand-Student Survey of Mechanics Test Data for Introductory Physics Courses. American Journal of Physics. I.-66. http://dx.doi.org/10.1119/1.18809

Halim, A., Suriana, \& Mursal, M. (2017). Dampak Problem Based Learning terhadap Pemahaman Konsep Ditinjau dari Gaya Berpikir Siswa pada Mata Pelajaran Fisika. Jurnal Penelitian $\mathcal{E}$ Pengembangan Pendidikan Fisika, 3(1). https://doi.org/10.21009/1.03101

Heller, P., Keith R., \& Anderson, S. (1992). Teaching Problem Solving Through Cooperative Grouping. Part 1: Group Versus Individual Problem Solving. American Journal of Physics. 60(7). https://doi.org/10.1119/1.17117

Hidayat, S. R., Setyadin, A. H., Hermawan, H., Kaniawati, I., Suhendi, E., Siahaan, P., \& Samsudin, A. (2017). Pengembangan Instrumen Tes Keterampilan Pemecahan Masalah pada Materi Getaran, Gelombang, dan Bunyi. Jurnal Penelitian \& Pengembangan Pendidikan Fisika,3(2), 157 -166. https://doi.org/10.21009/1.03206. 
Hoellwarth, C., Moeller, M. J., \& Knight, R. D. A. (2005). A Direct Comparison of Conceptual Learning and Solving Abilities in the Class Traditional Style of the and the Studio. American Journal of Physics, (73) 459. http://dx.doi.org/10.1119/1.1862633

Huitt, W. (1992). Problem Solving and Decision Making. Jurnal Psychological, 24, 33-44.

Juliawan, G. A., Putu, L., Mahadewi, P., \& Rati, N. W. (2017). Pengaruh Model Problem Based Learning (Pbl) Terhadap Kemampuan Pemecahan Masalah Matematika Siswa Kelas III. In Journal PGSD Universitas Pendidikan Ganesha Mimbar PGSD. 5(2).

Khairunnisa, Yusrizal., \& Halim, A. (2016). The Development of LKS Experiencing a Problem Based Learning -Charged Spiritual Attitude On the Material Measurement To Improve the Critical Thinking Skills of Students. Journal Of Scientific Students Of Physics Education . 1(4). Retrieved from http://www.jim.unsyiah.ac.id/pendidikanfisika/article/view/1315

Koedinger, K. R., Corbett, A. T., \& Perfetti, C. (2012). The knowledge-learning-instruction framework: bridging the science-practice chasm to enhance robust student learning. Cognitive science, 36(5), 757-798. 6709.2012.01245.x.

Mahardika, I.K., Riswati, L.I., \& Bachtiar, R.W. (2017). Study of Momentum and Impulse by Setting NHT Cooperative Model with Worksheet Based RGM for Senior High School. International Journal of Scientific Research and Management, 5(8), 68216827. https://doi.org/10.18535/ijsrm/v5i8.31

Menap, M., Bayani, F., \& Prayogi, S. . (2021). ProblemBased Learning in Phytochemistry Courses: Its' Effectiveness in Improving Medical Students' Critical Thinking Ability Viewed from Cognitive Style. Jurnal Penelitian Pendidikan IPA, 7(Speciallssue), 118-125. https://doi.org/10.29303/jppipa.v7iSpeciallssue.1 124.

Noprianda, M., Noor, M., \& Zulfiani, Z. (2019). Keterampilan Berpikir Kritis Siswa Model Pembelajaran Problem Based Learning Dan Sains Teknologi Masyarakat Pada Konsep Virus. EDUSAINS, $\quad 8, \quad$ 182-191. https://doi.org/10.15408/es.v8i2.3892

Nuraina, N., Muliana, M., Nufus, H. ., \& Zahara, S. R. . (2022). Developing Students' Worksheet Based Missouri Mathematics Project With the integration of Students Local Wisdom in Teaching Mathematics and Physics. Jurnal Penelitian Pendidikan IPA, 8(1), 147-155.

https://doi.org/10.29303/ippipa.v8i1.1134

Permendikbud. (2013). Attachment Permendikbud Nomor 81A Tahun 2013 on the Implementation of the
Curriculum Guidelines for General Learning. Jakarta: Ministry of Education and Culture.

Puspendik. (2015). Report the Results of National Examination SMA/MA Tahun pelajaran 2015. Jakarta: Puspendik.

Raehanah, R., Mulyani, S., \& Saputro, S. (2014). Learning Chemistry Using a Problem Solving Model Type Search Solve Create And Share (SSCS) in Terms of the Ability of Critical Thinking And the Ability Mathematically, the Journal Inquiry, 3(1). 19-27. https://doi.org/10.20961/inkuiri.v3i01.9652

Rahayuni, G. (2016). Hubungan Keterampilan Berpikir Kritis dan Literasi Sains pada Pembelajaran IPA Terpadu dengan Model Pbm dan Stm. Jurnal Penelitian dan Pembelajaran IPA, 2(2). 131-146. Retrieved from https://www.semanticscholar.org/paper/...d9371 Rahmadita, N., Mubarok, H., \& Prahani, B. K. (2021). Profile of Problem-based Learning (PBL) Model Assisted by PhET to Improve Critical Thinking Skills of High School Students in Dynamic Electrical Materials. Jurnal Penelitian Pendidikan IPA, 7(4), 617-624.

https://doi.org/10.29303/ippipa.v7i4.799.

Rizki, A., Khaldun, I., \& Pada, A.U.T. (2021). Dedevelopment of Discovery Learning Student Worksheets to Improve Students' Critical Thinking Skills in Chemical Balance Materials. Jurnal Penelitian Pendidikan IPA, 7(4), 707-711. doi:https://doi.org/10.29303/jppipa.v7i4.829

Rusman. (2011). Learning Models. Jakarta: PT Raja Grafindo Persada.

Selvianti, S., Ramdani, R., \& Jusniar, J. (2013). The Effectiveness of Troubleshooting Methods to Improve the Results of Belajardan Generic Science Skills of Students of Class XI SMA Negeri 8 Makassar. Journal of the chemical. 14(1):55-65. https://doi.org/10.35580/chemica.v14i1.793

Sugiyono. (2008). Quantitative Qualitative Assessment dan RED. Bandung: Alfabeta.

Sugiyono. (2012). Quantitative Research Methods, Qualitative and RED. Bandung: Alfabeta.

Sutarno, S., Setiawan, A., Suhandi, A., Kaniawati, I., \& Putri, D. (2017). Keterampilan Pemecahan Masalah Mahasiswa Dalam Pembelajaran Bandul Fisis Menggunakan Model Problem Solving Virtual Laboratory.Jurnal Pendidikan Fisika dan Teknologi, 3(2), http:// dx.doi.org/10.29303/jpft.v3i2.396

Trianto. (2009). Designing Innovative Learning Model Progressive. Surabaya: Kencana.

Zahrah, F., Halim, A., \& Hasan, M. (2018). Penerapan Praktikum Dengan Model Problem Based Learning (Pbl) Pada Materi Laju Reaksi Di SMA Negeri 1 Lembah Selawah. Jurnal Pendidikan Sains Indonesia, 5, 117-126. https://doi.org/10.24815/jpsi.v5i2.9826 
Zulfah, Z., Fauzan, A., \& Armiati, A. (2018). Pengembangan Lembar Kerja Peserta Didik Berbasis Problem Based Learning Untuk Materi Matematika Kelas VIII. Journal Pendidikan Matematika. 12(2), 33-46.

Zurraturrahmi, Z., Adim, A., \& Jalil, Z. (2016). Pengembangan lembar kerja peserta didik (LKPD) berbasis masalah pada pokok bahasan cermin untukmeningkatkan motivasi dan hasil belajarsiswa di smp negeri 2 banda aceh. Jurnal Pendidikan Sains Indonesua. 4(1). 178-186. Retrieved from

http://jurnal.unsyiah.ac.id/JPSI/article/view/659 $\underline{4}$ 